\title{
The Current Situation and Potential Responses to Movements against Gender Equality in Ukraine
}

\author{
Olena Hankivsky \\ School of Public Policy, Simon Fraser University \\ Marfa Skoryk \\ Institute of Social and Political Psychology, Kyiv
}

\begin{abstract}
Gender equality in Ukraine is facing resistance. Although this backlash is not uniquely Ukrainian, it can have profound consequences for Ukraine's efforts to integrate into the European Union. This paper reveals various aspects of a movement called "Stop Gender," examining letter writing campaigns, political lobbying and an anti-gender equality blog. It assesses the key arguments of the movement, considers their impact on gender mainstreaming efforts, and investigates what action might be taken in the face of growing anti-gender equality sentiments across all levels of Ukrainian society.
\end{abstract}

Keywords: Gender, anti-gender equality, "Stop Gender," feminism, gay rights.

\section{INTRODUCTION}

Cince the breakup of the Soviet Union, women's and gender issues in $\checkmark$ post-communist societies have received considerable attention (Funk and Mueller; Kuenhast and Nechemias; Mahon and Williams; Marsh; Rubchak; Štulhofer and Sandfort). Ukraine, however, has remained on the margins - or simply been absent from such analyses. More recently this has begun to change, with an emergent literature mapping advances in gender equality as well as noting the negative influence of tradition, persistent stereotypes, and government policies or lack of them (Coalition of Ukrainian NGOs, "Report to..."; Hankivsky and Salnykova; Rubchak). While these studies have furthered understanding of the complicated nature and uneven process of transforming gender relations in a post-communist society, they have not touched on the newest anti-gender equality developments in Ukraine, which warrant special attention. While the Ukrainian backlash is not necessarily unique, the impact of anti-feminist, anti-gender movements may be especially detrimental for Ukraine's aspirations to integrate with the European Union.

Because there is little awareness of these processes outside the Ukrainian context, the goal of this paper is to reveal-in an introductory 
manner-the various aspects of the anti-gender movement. We examine letter-writing campaigns, political lobbying and the anti-gender blog, "Stop Gender" (Stop-Gender). The goal is to assess the key arguments emanating from this movement, examine its impact on gender mainstreaming efforts, and to investigate what action may be taken in the face of growing antigender equality sentiments across all levels of Ukrainian society.

The paper begins with a brief description of Ukrainian history in relation to gender equality. It then moves on to describe the advent of the anti-gender movement, including its many elements and strategies. Based on information gleaned from a systemic collection of data by the Kyiv Institute of Gender Research starting in 2011 and culminating in a gender roundtable in Kyiv in February 2013 with leading non-government organizations from across Ukraine, the paper provides in-depth information about the movement's organizations, informational materials and the "Stop Gender" website. In particular, the paper subjects to critical feminist analysis key arguments of the anti-gender movement by examining two letters from the Lviv and Chernivtsi oblasts that exemplify the general thrust and content of this movement across the nation. The discussion then proceeds to an examination of how other jurisdictions have responded to similar phenomena, determining which tactics may be relevant or effective in Ukraine. The paper ends with suggestions of potential strategies and raises a number of important questions that gender activists and NGOs will need to answer if the future development and progress of equality in contemporary Ukraine is to be ensured.

\section{BACKGROUND}

Ukraine was one of the first countries in the world to adopt a constitutional guarantee of gender equality (Article 24, passed in 1996). As a UN founding member, Ukraine signed and ratified all the major international treaties related to human rights and women's rights, including the Convention on the Elimination of All Forms of Discrimination Against Women (1979) and the UN Millennium Declaration. Ukraine has also taken steps to align its governance and legal infrastructures with international norms and standards regarding gender equality. However, in 2010 the national machinery for promoting gender equality (established in 1995) became largely ineffective as a result of the elimination of the Ministry of Family, Youth and Sport that was charged with implementing gender equality throughout the government. A year later in 2011, the Ministry for Social Policy started to take over this responsibility but with far less political influence and financial resources. To date the most important law in Ukraine on gender equality is the Law on Ensuring Equal Rights and 
Opportunities for Women and Men (2005). Despite its promise, critics argue that it is not consistently implemented and widespread marginalization and discrimination of women continue (Hankivsky and Salnykova). Finally, Ukraine's newest gender equality plan-the National Program on Ensuring Equal Rights and Opportunities for Women and Men until 2016-has not been fully ratified.

On the world stage, the Ukrainian government has recently restated its commitment to human rights and gender equality. With regard to the Social, Humanitarian and Cultural Committee (the so-called "Third Committee") of the General Assembly of the United Nations and its agenda item 28, Ukraine's representative stated: "Ukraine considers ensuring women's right to equality before the law, to health, to decent job and property [sic], to participation at all levels not only as an important objective to achieve the Millennium Development Goals but also as an essential prerequisite for the progress of society as a whole" ("Statement by..."). On March 8, 2013, Ukraine's foreign minister Leonid Kozhara, then head of the Organization for Security and Co-operation in Europe, stated that gender equality was key to economic and social growth. And yet, in the Global Gender Gap Index ${ }^{1}$ for 2012, Ukraine was ranked $64^{\text {th }}$ just above Thailand, Vietnam, Romani and Timor-Leste. Ukraine was also ranked 27 out of 86 countries in the 2012 OECD Social Institutions and Gender Index (OECD), a measure of gender discrimination in social institutions. In general, there is a widespread belief that even though Ukraine is a signatory to numerous international conventions and has established important national laws, gender equality is not a priority of the Ukrainian state. Currently this is further exacerbated by an increasingly powerful national anti-gender campaign that is affecting public and political perceptions of the value of gender equality for Ukrainian society.

\section{The ANTI-GEndER EQUALITY MOVEMEnT In UKRAINE}

Susan Faludi's 1991 book (reissued in 2006) established "backlash" as a term that describes counterattacks against feminism in all sectors of society, including media, advertising, film, popular psychology, and politics (Faludi; Braithwaite). These are not necessarily confined to a specific time or place but can be recurring phenomena, as is evident in present resistance to gender equality and social change in Western and non-Western contexts.

1 The World Economic Forum publishes this index. It measures: economic participation and opportunity; educational attainment; political empowerment; and health and survival. 
Writing about post-socialist European countries, Galligan, Clavero, and Callonihave have argued that "[s] tereotypes of western feminists as 'manhaters' resonate strongly across post-communist Europe, as societies continue to have strong memories of the importance of the collusion and alliances of women and men in opposition to the totalitarian regime" (28). Not surprisingly, anti-feminist rhetoric is a regular part of the public discourse in post-communist countries. Arguably, democratic transformation in this region has one thing in common: an "allergy to feminism" (Kis). And the allergy persists. In April 2013 The Guardian reported that Patriarch Kirill, head of the Russian Orthodox Church, speaking in Moscow to a meeting of the Union of Orthodox Ukrainian Women, said: "I consider this phenomenon called feminism very dangerous, because feminist organisations proclaim the pseudo-freedom of women, which, in the first place, must appear outside of marriage and outside of the family." He went on: "Man has his gaze turned outward-he must work, make money-and woman must be focused inwards, where her children are, where her home is." Kirill ended by arguing that "If this incredibly important function of women is destroyed then everything will be destroyed-the family and, if you wish, the motherland." Kirill's position is that feminism wrongly leads women to look outside of the traditional family for fulfillment, a move that is contrary to family values because women are first and foremost "the guardians of the family fire, the centre of family life" (Elder).

In Ukraine, anti-gender equality organizations and concomitant discourses gained significant traction when Viktor Yanukovych was elected President in 2010. As part of the general backlash against Western values and ideals, the anti-gender movement became very influential between 2010 and 2012 (Coalition of Ukrainian NGOs, "Report to..."). Its rise was part of a general trend that reduced political openness and eventually resulted in the Euromaidan protests of late 2013. "Stop Gender" is particularly well orchestrated and funded. It is characterized by 'message consistency,' using the same packages of documentation and the same channels of advertising. The first document of the movement was a free online booklet (available in Ukrainian and Russian), Gender without Embellishment: Through Gender Equality Policy towards the Dictatorship of Homosexualism (Gender bez prikras...). The next was an article by Liudmyla Hrydkovets' (Kyiv Institute of Business and Technology), titled "Genderequality Extremism as a Factor of Family Destruction" (Hrydkovets' 301311). The article and booklet initially served as a manifesto of the movement. With time, these materials expanded to include two films: Stop Gender (2011) and The Dangers of Juvenile Justice (2012) as well as a brochure, Gender 'Education' (Genderne 'vykhovannia'...'). These 
publications have been widely disseminated, reaching all levels of government, including the Parliament of Ukraine.

Currently the anti-gender movement has two centres: one in the West, the other in the East. Key players include the "Ukrainian Orthodox Greek Catholic Church," which does not have status as a recognized church in Ukraine. This group identifies as an NGO and calls itself "Charismatic Catholics." It is very active in Western Ukraine, where there are high levels of religiosity and nationalist feelings (Kis). It has been the object of a New York Times article (Higgins). The organization has a number of regional branches, such as Family under the Holy Mother's Cover, Youth for Healthy Lifestyle, Lord's Voice, and The Union of Christian Mothers. These organizations are also closely related to similar Protestant Christian groups, including Love against Homosexuality (Liubov' protiv homoseksualizma), which has received international media coverage.

The Orthodox movement has an analogous organization called the Orthodox Parent Committee. It claims to have the blessing of the head of the Ukrainian Orthodox Church (Moscow Patriarchy), which is the most influential church in Ukraine. In contrast to its Catholic and Protestant counterparts, this group has a very rigid hierarchical structure and is active mostly in Eastern Ukraine. Of course, this list of organizations is far from exhaustive.

The above-mentioned groups have used similar methods for their informational campaigns: they prepare and post website documents that can be downloaded, printed, signed and mailed to addresses that are posted on their websites. This successful tactic has led to a virulent writing campaign nationally and has targeted government officials at local and national levels. Websites, which come and go, at one time contained prepared letters addressed to a number of MPs, the President, Prime Minister, Minister of Social Policy, Minister of Health, Minister of Education and Science, and Chairs of Parliamentary Committees. The content of these letters-all of which are in possession of the authors-focused on a lawOn Providing Equal Rights and Opportunities to Men and Women (2005)and a 2012 bill-On the State Targeted Social Program to Enable Equal Rights and Opportunities for Women and Men for the Period till 2016. The authors of such letters argue that gender equality legislation gives de jure support to homosexuality. These campaigns (e.g., in Ivano-Frankivsk, April 2011) claim: "Your letter will save Ukraine." The latter action had the goal of "protecting traditional families from homosexuality, gender policy and juvenile justice in Ukraine." Organizers predicted that volunteers in white T-shirts would persuade the residents of the city to write a letter to the President of Ukraine with the request "to not allow the destruction of family 
values in Ukraine." Similar civic actions took place in Lviv, Ternopil, Sambir, Stryi, Truskavets, Rava-Ruska and Chervonohrad.

\section{THE “STOP GENDER” WEBSITE}

A critical aspect of the movement to date is the anti-gender blog "Stop Gender" (Stop-Gender). It claims that traditional family policy has been transformed in Ukraine into gender policy, which promotes tolerance and liberalism and the idea that traditional family values are outdated. The site also claims that gender policy is dangerous and will affect citizens in all areas of their lives: from the upbringing of their children, to the interpretation of the Criminal Code, and even in terms of the size of their paycheques and pensions. Firmly entrenched in the content of the website are gender biases, stereotypes and assumptions that are widely accepted as natural and normal (Carrera, DePalma, and Lameiras).

The postings on the website embrace a range of topics-from world news (e.g., President Obama's lobbying for sexual minority rights as an aspect of US foreign policy) to 'scientific' commentaries on the bioethical implications of gender policy and the benefits of traditional separation of gender roles. The latter point, for example, is discussed through a synopsis of a study that came out of Warrington College of Business Administration at the University of Florida. A team of economists headed by Tim Judge reported the results of a longitudinal study that looked at how views on gender equality influences the size of one's paycheque. Salaries of males who held traditional views on gender roles in the family were on average $\$ 8,500$ higher than of those who held more egalitarian views. For women this difference was also higher-but only by $\$ 1,500$. While the Warrington College study concluded that this gender gap in salary was a sign of sexism (Judge and Livingston 1009), the "Stop Gender" site did not mention this conclusion and interpreted the article to suit its position, i.e., that traditional gender roles in the family are financially advantageous. Nor did it emphasize that benefits accrued primarily to males.

Another example of the misinterpretation of facts is a news story about how preferences for sons in India result in thousands of sex-change operations for girls. According to the "Stop Gender" site, this torture of girls is the consequence of a gender theory that sanctions the artificial change of sex. Surprisingly, this posting received a comment from a woman named "Natalia" who argued that the problem of son preference in India underscored the need for gender mainstreaming. The response from the website authors was that such torturous treatment of girls has become a reality in the last decades, i.e., with the dawn of gender theory and the LGBTQ movement. In their view, traditional manifestations of male/female 
divisions in society are much more "benevolent." Natalia responded that such a position is outrageous because "the traditional culture" in India results in sex-selective abortions and in poor treatment of girls who often experience malnourishment and lack of education. Natalia suggested that the authors of this posting are either consciously misinforming their readers or have a wrong understanding of gender theory. She urged them not to support harsh treatment of women by their misinterpretation of gender mainstreaming. The final response from the authors was: "Natalia, why don't you change the sex of your daughter, everyone should always start with themselves."

Among other forms of misinformation on the site is the idea that gender policy is a new phenomenon, purported proof of which is that even Microsoft Word does not recognize the phrase. There are some items-e.g., the fundamental sixty-page brochure, Gender without Embellishments (Gender bez prikras) - that show signs of research and present a lot of information about gender mainstreaming and the LGBTQ movement in Western countries. However, some statistics lack references and/or come from questionable sources, as in the brochure Gender 'Education' (Genderne 'vykhovannia'... 12, 34, 36). In general, facts are interpreted in such a way as to support the main message of the "Stop Gender" site and movement, namely, that gender mainstreaming will lead to a homosexual dictatorship of a minority over the majority of Ukrainians who maintain traditional family values. The authors of the brochure argue, for example, that Ukrainian legislation on gender equality-influenced by EU agreementswill lead to the same purported outcomes currently being experienced by Western Europe: high rates of abortion, low birthrates, and rampant growth of the LGBTQ community, both in numbers and in influence.

\section{The Movement's Key ANTI-GENDER ARGUMENTS}

\section{Sex, gender, gender identity and sexuality}

The movement lacks an understanding of sex and gender-especially the relationship between the two. This is made obvious in an unsigned letter (a copy of which is in possession of the authors) to the Lviv Regional State Administration in 2011, which, referring to the negative effects of gender equality, puts forward the following argument:

We are reminded once again that gender is a social sex; it's as if who a person is born (biological sex) is not important; it's what she feels (social sex) [that's important]. Gender tries to fully substitute the word sex. Besides, it turns out that there are not two sexes, but at least five, which includes all the perversions. In other words, gender policy aims to legitimate 
perversions and initiates the so-called child's right to choose sex. ("Lviv Regional State Administration's Decree...")

According to the unnamed authors, gender is (or should be) inextricably linked to biological sex. They are apparently not aware that feminist theory and gender scholars have long asserted distinctions between sex and gender. At the risk of stating the obvious, "Sex" refers to the biological aspects of maleness and femaleness: gametes, chromosomes, the anatomy and functions of internal and external reproductive organs. A useful definition has been advanced by the World Health Organization: 'Sex' refers to the biological and physiological characteristics that define men and women"; "[m]ale' and 'female' are sex categories" (World Health Organization). In other words, biology is not destiny and gender roles are not determined by sex. Raewyn Connell's definition of gender is instructive: "Gender is the structure of social relations that centres on the reproductive arena, and the set of practices (governed by this structure) that bring reproductive distinctions between bodies into social processes. Gender arrangements are reproduced socially (not biologically) by the power of structures to constrain individual action, so they often appear unchanging" (11). Gender is in fact fluid allowing for many expressions, allowing persons to be women or girls, boys or men, or transgendered (Devor and Matte), in other words, possessing gender identities that are not consistent with their biological identity.

The letter to the Lviv Regional State Administration, as we saw above, made mention of at least five sexes. The "Stop Gender" website refers to five genders: male, female, homosexual, bisexual, and transsexual. This not only conflates sex with gender again, but also ignores biologists who have demonstrated that sex is not a unitary phenomenon, and that human beings do come in the form of intersex (Adkins; Findlay; Reis). This is a fact that was not created by feminism, gender theory, or the European Union but is an observable biological phenomenon. Even though certain cultures are deeply committed to the idea that there are only two sexes, there are in fact many gradations, running from female to male. Indeed, the biological continuum knows many types of intersex conditions. It is therefore incorrect to refer to homosexuality, bisexuality and transsexuality as genders given that the social organization and expression of human sexuality are neither timeless nor universal (Fausto-Sterling).

\section{Gender equality leads to the destruction of the family}

A major second theme of the anti-gender movement is the idea that gender equality is necessarily anti-family. The letter writing campaign, as demonstrated by the correspondence received by the Lviv Regional State 
Administration, treats equality between men and women as a Marxist notion: "Friedrich Engels... argued that: 'The first social conflict happened when inequality between man and woman increased..."' The Lviv letter emphasizes that, according to Marxism, "to eliminate inequality, the first class conflict between man and woman should be eliminated and that in practice this means that the family should be destroyed." The letter goes on to state, "Gender ideologists strive for the elimination of domestic violence but in practice this means making man a weak and spineless creature, and the female a cruel feminist, ridiculing maternity and legitimizing all the perversions to the level of sex" ("Lviv Regional State Administration's Decree..."). While the letter mentions domestic violence, as well as other types of violence that occurs within family settings (e.g., different forms of child abuse), violence as such is neither problematized nor condemned. In 2012, according to the Ukrainian Ministry of Social Policy, there were 110,002 petitions registered concerning domestic violence; of these 93,402 came from women and 15,902 from men ("Information of the Ukrainian Parliament Commissioner..."). There is serious doubt whether these data are in fact accurate. As in many other jurisdictions, official statistics always underestimate the true seriousness of interpersonal violence. The authors of the letter, however, appear to insinuate that efforts to eliminate domestic violence will lead to undesirable and tragic changes in the 'ideal' man and woman.

The claim that gender equality leads to the destruction of the family leaves no room for thinking about transforming traditional family structures to advance equality of opportunity, as well as more equal distribution of male and female roles and responsibilities in the private and public spheres. For example, the active promotion of the image of the Berehynia-i.e., mother figure, goddess, protectress of hearth and home (very prevalent in all sectors of Ukrainian society) - has been identified as especially problematic from a gender perspective (Hankivsky and Salnykova). The latter does not acknowledge other, currently existing, realities of the family. In Ukraine, lone parent households (e.g., single mothers or fathers) exist, not to mention many other types of family formations outside of the nuclear heterosexual unit. Further, there are nearly 96,000 children living in state institutions because of family poverty, unemployment, alcoholism and drug use. Thousands of children also choose to run away from violence in their homes ("Children in Ukraine").

\section{Conflation of gender equality with homosexuality}

According to Gender 'Education,' a forty-eight page brochure on the "Stop Gender" website, gender mainstreaming, as mentioned, will result in a homosexual dictatorship, i.e., a minority dominating the Ukrainian majority 
that maintains traditional family values. "The homosexual lifestyle is already popularized to our children under cover. It is all happening under the guise of gender policies, anti-discrimination laws, laws about the 'rights of children and women,' HIV/AIDS prevention and trafficking, as well as imaginary family violence" (Genderne 'vykhovannia'... 3).

Needless to say, none of the international literature on gender mainstreaming makes such claims or argues for such goals. No evidence exists that gender policies advocate for or have implemented a 'homosexual dictatorship.' In this context, it is important to note that in 1991 homosexuality was decriminalized in Ukraine. In recent months, however, a bill, duplicating Russian legislation that was signed in June 2013, has been introduced in Parliament. It would ban the production, publication, or distribution of materials "promoting" homosexuality. LGBT NGOs in Ukraine keep pointing out that homosexuality is not a disease or a personality disorder. For this they experience violence and harassment from nationalist groups, police and fellow workers ("Ukraine: Investigate Violence...").

In addition to the anti-gender movements, there is also a powerful, anti-LGBT movement called Love Against Homosexuality. It regularly protests and distributes information, conveying the following messages: homosexuality=AIDS; "you are not born gay, you become gay" (Semeinyi karnaval, Photo 224); "there is no single-sex love" (Semeinyi karnaval, Photo 219); "Ukraine is a Christian country"; and "Homosexuality is the enemy of the family" (see http://love-contra.org/index.php/gallery/). The organization's website promotes the message that the popularization and acceptance of homosexuality is a danger to national security because it will lead to an AIDS epidemic, that it exacerbates the existing demographic crisis in Ukraine, and that it destroys the institution of the family. Moreover, there are explicit references made to the gender revolution, which makes allowances for the widespread acceptance of homosexuality. The site accuses western institutions such as the EU and UN of imposing gender ideology on Ukraine, much in the same totalitarian way as Moscow tried to impose communism (Liubov' protiv homoseksualizma).

Martsenyuk argues that homophobic attitudes within Ukrainian society are intensifying, especially among faith organizations. Indeed, public opinion polls show the same. For example, the number of people who think homosexuals should enjoy equal rights has decreased from $43 \%$ in 2002 to $36 \%$ in 2011; the number of those that believe the opposite has increased from $34 \%$ to $49 \%$ (Nash Mir 12-13). Increasing homophobia, including homophobic aggression and violence, can be at least partially linked to the Ukrainian government's neglect of LGBT issues, the growing influence of the Church and other conservative forces, and homophobic statements 
made by politicians and government officials (Nash Mir). While equating gender equality with homosexuality is an inherently flawed argument, it is nevertheless a powerful strategy for undermining the advancement of human rights and killing, so to speak, two birds with one stone.

\section{Gender education will turn boys into girls and girls into boys}

In a letter to the Head of the Chernivtsi Oblast Council dated 2012, proponents of the anti-gender movement asserted that gender education "will pervert children's psyche" and create confusion and promote changes in natural gender roles. Despite the fears of the anti-gender movement, effective and transformative education around gender stereotypes is far from a reality in Ukraine. For instance, Olga Plakhotnik's research shows that "Ukrainian schoolteachers have poor knowledge of gender equality principles and they hardly recognize gender inequalities in educational contexts" ("Gender Policy..." 229). This is evidenced by other research in Ukraine. A survey by Hovorun and Kikinezhdi showed that $75 \%$ of teachers agree that girls must be prepared for the roles of mother and housekeeper, and boys for the role of breadwinner. Plakhotnik ("K voprosu...") pointed out that nearly $50 \%$ of teachers in the social sciences and humanities agreed with the statement that the sex of a child predetermines the way he or she learns and the way they should be taught. A recently completed analysis of textbooks (Semikolenova) demonstrated just how deeply gender stereotypes are rooted within the educational sector and to what extent they do real harm by creating an environment for gender asymmetry and hierarchy, which is harmful to both boys and girls.

According to the European Parliament (Committee on Women's Rights and Gender Equality), children are confronted with stereotypes at a very early age through role models promoted by television, discussions, games, advertisements, study materials and educational programs, as well as attitudes expressed in schools, the family and society. These influence their perception of how men and women should behave and thus have implications for their lives and their future aspirations (Cassell and Jenkins; Cherney and London). Indeed, early gender bias experiences can profoundly shape human development, interpersonal relationships, educational and labour participation and success, not to mention physical and psychological well being (Wei and Hendrix). Naturally, education about gender stereotypes does not make boys into girls or vise versa. Instead, it exposes both to the full range of possibilities and experiences, ensuring that they have equal opportunities to realize their human potential. The antigender movement does not grasp this fact. 
Gender education will lead to moral, demographic, and spiritual genocide

The above-mentioned letter to the Head of the Chernivtsi Oblast Council (2012) also makes the claim that establishing educational gender centres, such as the one proposed for the Chernivtsi National University, will lead to a range of genocides of the Ukrainian population and its culture. The notion that such a centre might have such consequences is, of course, patently absurd and overlooks the fact that Ukraine already has a demographic crisis, completely unrelated to gender education. According to UN figures, Ukraine has one of the world's lowest birthrates; it has seen its population decrease steadily since 1993 (United Nations...). According to Euromonitor International, the country is projected to experience the single largest absolute population loss in Europe between 2011 and 2020. Economic hardship, poverty, unhealthy lifestyles and growing HIV epidemics are the main causes of Ukraine's demographic crisis. The HIV/AIDS crisis in particular (one of the fastest growing in the world) was clearly not caused by homosexuality but by an epidemic of drug use, spread by needles and unprotected sexual relations (Yorick et al.).

\section{IMPLICATIONS}

As of this writing, the influence of the anti-gender movement is tangible and growing. La Strada notes, "By spreading false information on the Internet, in schools and during street actions, they [members of the movement] mislead not only the general public on the activity of human rights and women's organizations, but also government representatives, who seemingly should protect norms and principles of Ukrainian legislation in this field" (Coalition of Ukrainian NGOs, "Ukraine: Review..." 8). Oksana Kis similarly concludes: "Their zeal and the scope of their actions in exposing the 'threats' of gender policy is quite astonishing; they stop at nothing to discredit their 'ideological foes'” (n.p.). Indeed, beyond letter writing, public demonstrations and information dissemination tactics, members of the movement participate actively in local legislative assemblies, attending meetings of civic groups on gender issues that have been created in some executive offices (e.g., the Ministry of Education and Science). In so doing, they demonstrate their close ties and cooperation with members of legislative assemblies. Lviv, Rivne and Volyn oblasts were among the first regions where the anti-gender activities started. They also reached Central and Eastern Ukraine, including Luhansk, Odesa, Kyiv, Kharkiv and Zhytomyr. However, perhaps due to the relatively low levels of religiosity in these regions, the anti-gender movement has not taken as strong a hold there, although it has influenced some regional elites. Western Ukraine is, therefore, a good example of what has transpired. 
In February 2011, Sviatoslav Sheremeta, a member of the Verkhovna Rada from the Narodnyi Rukh Ukrainy party, announced at a session of the Lviv Oblast Council, "Ukrainian society should not permit the spread of ideas about sexual orientation of minorities in spheres of children's learning and upbringing" (“Deputaty L'vivs'koi oblrady...").

Perhaps the most poignant example of the reach of the movement is illustrated by a case in Rivne oblast'. On March 6, 2012 a round table took place devoted to the topics of gender mainstreaming and juvenile justice. Among the participants of this round table were local authorities, lawyers, NGO activists, religious leaders from different churches and professionals in the area of health, psychology, pedagogy, and law. The roundtable was organized in response to fears that Ukraine's Euro-integration was introducing values that contradict Christian ideals and lead to the moral degradation of Ukrainians. Arguments advanced at the round table were identical to the ones presented on the "Stop Gender" website. For example, Olesia Zhupnyk, identified as being from the Czech Republic, presented examples of how gender mainstreaming impacted some European countries. Her key message was that gender mainstreaming leads to destructive consequences: deformation of the role of men and women, and legalization of sexual perversions (Dovbush). What makes the event especially noteworthy is the active participation of representatives from Rivne legislative and executive authorities. The round table was initiated by Svitlana Levyts'ka, the Head of the Commission on Science, Education, Culture and Spirituality at the Rivne Oblast Council. Mykhailo Kryvko, First Deputy of the Rivne Legislative Assembly, and Viktor Marchuk, the Head of the Commission on Children's Affairs at the Rivne Oblast Administration also supported this event (Dovbush).

A similar occurrence took place in Volyn. A special session of the oblast' Legislative Assembly investigated the foundations of gender mainstreaming and the problems and risks it represents to Ukrainian society. Antonina Evtodiuk, Chair of the NGO Christian Movement for Life, initiated it. This NGO prepared materials and information for the sessions using the arguments of the "Stop Gender" website. At the session, Evtodiuk proposed the following policy options:

1. The Parliament of Ukraine should initiate Parliamentary Hearings to investigate the topic of gender mainstreaming and its dangers;

2. All local and regional offices of legislative and executive powers in the Volyn region must read the materials and conclusions of the sessions that took place in Volyn;

3. The Department of Children's Affairs, and the Department of Family, Youth and Sport in Volyn should monitor events connected to gender mainstreaming that take place in Volyn and evaluate their consequences. 
As a result of consolidated lobbying activities by powerful and wellknown gender experts and NGOs, Evtodiuk's recommendations were not put into practice. Still, this example demonstrates how the anti-gender movement is becoming increasingly enmeshed with government authorities ("10 lypnia sesiini slukhannia..."). Events similar to the Volyn round table have taken place elsewhere. In Kamianets-Podilskyi a conference was organized under the slogan, "Gender Propaganda is a Crime." Some of the statements that came out of this conference included: "Gender mainstreaming and juvenile justice are components of a project that is presented in Ukraine as 'right of women and children' but in reality this project ruins all women's rights, destroys motherhood and legalizes perversions" ("Otets' Pavlo...").

While one can observe the influence of the movement on local governments, it is also true that there have been some official government responses that have confronted anti-gender messages. To illustrate: in 2012 the Chernivtsi Regional State Administration, Education and Science, Youth and Sport Department wrote a letter of explanation to the Byzantine Catholic Patriarchate, and the Public Prosecution Office in Chernivtsi Region about Ukraine's commitment to gender equality and human rights. In response to a letter campaign, the Ministry of Justice of Ukraine also prepared a special explanation about what the gender policy is and what it is not. In responding, the Ministry clarified:

According to paragraph seven of article 1 of this bill, gender equality means that women and men have equal legal rights and opportunities, allowing them to participate equally in all spheres of society. The bill regulates legal relations that enable equal rights and opportunities for women and men in political and socioeconomic spheres, in civil society and education; [the bill also regulates] mechanisms through which various institutions, establishments and organizations can ensure equal rights and opportunities for women and men. (Ministerstvo iustytsii Ukrainy)

Government responses, however, have been inconsistent and even contradictory. For example, on May 24, 2012, the State Registration Service sent a letter to an NGO human rights organization in Ukraine demanding comprehensive reporting on activities within a two-week period. This request was motivated by a letter writing campaign by "concerned citizens" who were protesting against the activities of human rights organizations, which are increasingly seen as mechanisms for undermining the institution of the family, marriage, gender relations, and the state and, in general, all traditional values. Moreover, the position of gender advisors at the oblast' level has come under fire. The appointment of gender advisers started in 2007 and the UNDP (the UN Development Program) reported that advisers 
were appointed in 18 oblasts in 2010: Vinnytsia, Volyn, Donetsk, Zhytomyr, Zaporizhzhia, Kyiv, Luhansk, Lviv, Mykolaiv, Odesa, Poltava, Rivne, Ternopil, Kharkiv, Kherson, Khmelnytskyi, Chernivtsi and Chernihiv. According to available information at least four of these positions have been eliminated in Khmelnytskyi, Poltava, Rivne and Chernivtsi oblasts (“Intermediate 2010 Report...").

Finally, the anti-gender movement singles out some women's rights organizations and even specific people as targets of their criticism. This is evident not only from the content of the various letters circulating across the country; these efforts have now been advanced through social media. For instance, there are some anonymous video and text information messages about "genderists" from La Strada and UNICEF on the topic of "Ukraine without Orphans." These organizations are blamed for such horrible crimes as child trafficking ("Ukraina bez syrit...").

\section{CONCLUDing ThOughts}

As Kathy Davis argues, the backlash against feminism is taking a toll everywhere one looks. The lack of progress on gender equality and, in particular, the need to address persistent gender stereotypes are being prioritized throughout the European Union, an important consideration for any country that is either part of the EU or, as Ukraine, aspiring to EU accession. For example, in December 2012, the Committee on Women's Rights and Gender Equality concluded: "the prevalence of negative gender stereotypes based on societal beliefs and attitudes affects women and constraints their opportunities and choices in the social, economic and political sphere. In order to tackle the problem of the lack of women at the higher levels of economic and political decision-making, the persistence of gender stereotypes in all levels of society needs to be addressed" (Committee on Women's Rights and Gender Equality 16)

If Ukraine is intent on EU accession, institutionalizing equality, including responding to threats to gender rights, which are already having widespread influence, will have to be taken seriously. Responses to the antigender movement within Ukraine, however, are only starting to emerge. One proposal to date includes strengthening the national policy on gender, including its informational and educational components across all sectors of Ukrainian society (Coalition of Ukraine NGOs, "Report to..."). This suggestion is critical for a number of reasons. First, over the last twenty years, different sectors in Ukraine have been educated and informed in different ways about gender equality. As Skoryk has documented in great detail, there are key stakeholders that have not received any exposure to gender issues. Thus, while international organizations and Ukrainian 
organizations seeking to establish equity have instituted various activities on gender mainstreaming, these have been largely limited to civil servants. Very little training and outreach has taken place among politicians, NGOs, business, religious and cultural leaders. The unintended result is knowledge asymmetry about gender equality across sectors and important stakeholders. Not surprisingly, this makes some elites vulnerable to the anti-gender movement's influence. This vulnerability extends to the general public whose lack of access to information and understanding about gender equality has been well documented (Hankivsky and Salnykova; Rubchak). In such circumstances, the anti-gender movement has been extremely successful in "discrediting the very concept of gender and making it effectively unpalatable for the broader public" (Kis).

In seeking a strategic response to the anti-gender movement, Ukraine may benefit from the experience of other jurisdictions. For example, in November 2012 a report to the Nordic Council, "How to Oppose Antifeminism and Right Extremism? Proposals and Recommendations from Experts in the Nordic Countries" (Nordic Council) specifically tackled the issue of anti-feminism. Here, anti-feminism is defined as an attitude, a behaviour and an action, an opposition to feminism and equality, a desire to recreate a hierarchical social order in which heterosexual men are privileged, and resistance is mounted to any challenge of traditional gender, sex and race categories. Explicitly defining the characteristics of the antigender movement in Ukraine would also seem a crucial first step in terms of developing a targeted response. Moreover, although Nordic countries are generally thought to be more advanced in terms of gender equality, even this jurisdiction is confronting anti-feminist forces. Describing the situation in Iceland, Ásta Johansdottir states:

The elite of powerful men in Iceland seem to stick together so to speak. This power network expands to the media, the legal system, the political system, the academia, to different organizations and between men of power in society, all of whom are contributing to normalizing negative attitudes to women and immigrants." (Nordic Council 32)

In Finland, activists started a blog-Feministen Vouro-to respond to antifeminist claims. According to one of the blog's founders Katariina Maakinen, "we started up the blog to... be a counter voice to antifeminism, and contribute to real and open discussion in a controlled space" (Nordic Council 34).

The recommendations of the Nordic report are quite comprehensive. Perhaps the most important as well as the most controversial is the suggestion that anti-feminist threats and harassment be made illegal (Nordic Council 35). Even though the policy prescriptions in the Nordic 
report originate in the West, they offer important insights and potential directions in the Ukrainian context, especially if they are prioritized and appropriately tailored to the situation. For instance, the report recommends organizing a Nordic conference on extremism and gender. It would be useful to consider a broader conference that would include other jurisdictions, such as Ukraine, which are particularly challenged and isolated in their struggles. Given that international organizations and donors are so essential to sustaining gender equality efforts in Ukraine, it also seems important that they become aware of the strength and threat of the anti-gender movement to ensure, as the Nordic report suggests, that resources may be devoted to increasing research of this phenomenon and especially to ensure that annual mapping and documentation of the antigender movement is conducted and disseminated widely, including in English. While civil society organizations are already coming together to try to coordinate such efforts, they may consider further consolidating their responses by following the example of Finland and organizing a website and/or blog to formally respond and confront the misleading and wrong information being systematically disseminated by the anti-gender movement.

Without doubt "civil society [in Ukraine]...appears to offer a real chance for gender democracy, for equal participation of men and women" (Sauer 286). Alexandra Hrycak has persuasively argued that it is openness to western influence and pro-western political advocates that has allowed women's groups to have an effective voice in the face of conservatism and patriarchal discourses. Civil society organizations have appealed to all levels of government to develop a comprehensive and strong response to false informational campaigns that have infiltrated the country. The lack of swift, systemic and sustained rebuttals, however, leads one to recall the warning advanced by Wendy Brown in her seminal work States of Injury. Brown warns that any engagement with the state (and she does assume a liberal democratic state) necessitates compromise because it requires conceding to power structures that are already in and of themselves oppressive. She writes " $[w]$ hether one is dealing with the state, the Mafia, parents, pimps, police, or husbands the heavy price of institutionalized protection is always a measure of dependence and agreement to abide by the protector's rules" (Brown 169). It may therefore be inadequate to expect too much protection from the state in relation to the anti-gender movements. Instead, civil society organizations in Ukraine may need to forego even "situational cooperation" (Kis) and will need to focus on tactics and strategies that are not reliant on the state and/or government machinery and depend rather on "the consolidation of the efforts and potential of scholars, educators, and media, as well as civil rights 
movements and women's organizations" (Kis). A critical development in this regard has been the establishment of the Gender Strategic Platform, consisting of leading NGOs in Ukraine, which are committed to retaining the institutional memory around gender mainstreaming in Ukraine. Another more radical example is Feminist Offensive that declares its rejection of all forms of collaboration or cooperation with the authorities (Feministychny ofenzyva). It has recently disbanded.

At the same time, as Natasha Bingham reports, there are important challenges facing women's organizations in Ukraine. In the words of a participant in Bingham's study:

[S]o many women's organizations are based on traditionalist attitudes and appeal to traditional female roles - wives, mothers and housewives. Today the situation is complicated for women's organizations in a number of circumstances: 1 . The preservation of the role of the traditionalist discourse in relation to gender roles (even in gender programs); and 2) significant steps backward in gender democracy in Ukraine, with the arrival of President Yanukovych [...]. (quoted in Bingham 29)

This of course may hamper the ability of women to confront some of the attacks of the anti-gender movement. On the other hand, there is also the rise and growth of FEMEN, infamous for staging topless protests. This form of feminism is often seen as antithetical to what Ukraine needs and is seen as reflecting a type of "radicalism [...] similar to American feminism" (quoted in Bingham 29). Others simply question whether FEMEN even has a point to make (Murphy).

The influence and reliance on western donors entails some conformity with western models of gender and culture. This influence has also been central in anti-gender arguments, including the letter to the Lviv Regional State Administration in which the authors accuse the oblast' administration of copying its Methodology of Gender Policy and Program Analysis in the Lviv region directly from Canadian manuals. Although this claim is factually incorrect, it does raise an important issue, namely, that any gender mainstreaming efforts should be context driven, engage with appropriate stakeholders and be "sensitive to Ukraine's socio-historical context, including specific norms and assumptions regarding language, gender roles, and stereotypes" (Hankivsky and Salnykova 435). Nevertheless, it is also the case, as Galligan, Clavero, and Calloni persuasively argue, that western linkages offer cooperation and interaction that prior to the breakdown of the Soviet Union were simply impossible and without which there would be no funding for gender activism in Ukraine.

The anti-feminist, anti-gender movement in Ukraine and similar trends elsewhere also raise some fundamental questions about how to move 
forward with trying to address inequities, how to advance human rights and gender equity in particular. In recent years, some current and former activists have asserted that "feminism was dead, dying, or - at the very least - on its last legs" (Davis 279) and put forward the very poignant question "is feminism relevant to the new millennium?" (to cite the title of Coward's book). This line of argument does require consideration of difficult issues. The first question is whether it is true either for the feminist or antifeminist movements that there is "something easily (and continuously) identifiable as 'feminism' to begin with, which can be used as a measuring stick [...] to gauge the 'backlash' (Braithwaite 25). Although she made her observation almost 15 years ago, Diane Elam is correct in observing that "While the backlash against feminism must be taken seriously [...] merely instituting protective measures against threatening patriarchal intruders would be too simple a solution to the problem. Rather [...] it is important to ask some serious questions about what is happening within feminism [...]" (55). Specifically, is it enough to only think about binary models of power relations, of coherent conceptions of male advantage and female disadvantage (Coward), as do many feminists when they foreground only patriarchy?

This general question leads to additional lines of inquiry. To what extent do civil society organizations that seek to advance equity take into explicit account interactions between ethnic background, socio-economic status, age, sexual orientation, geography, religion and disability? Su-lin Yu has argued that such considerations are consistent with a third wave of feminism, which has developed in relation to the backlash against feminism and in particular the totalizing and homogenizing tendencies of mainstream feminism in which women are conceptualized in an essentialist and static fashion (69). In Eastern Europe, Polish feminists have argued that feminism in their country is "a particular mixture of second wave feminist goals and third wave feminist themes and tactics" (Graff 143). Examples from Poland, where activists take explicitly coalitional approaches to political struggles, combining activism on feminist, environmental and LGBT issues (Binnie and Kless), are particularly instructive. According to Binnie and Kless, "the close cooperation between feminist and LGBT movements was further enhanced by a coincidence of a mobilizing momentum and the shared abject position of feminist and LGBT activities in dominant Catholic and nationalistic ideologies" (456).

Recently Hankivsky and Salnykova concluded that the next phase of research and activism in Ukraine should challenge the confines of genderspecific approaches. It should explicitly include other factors and social locations, including age, race/ethnicity, geography, sexuality, ability and religion, all of which may contribute to social inequality and discrimination. 
Here it is worth noting that while the EU continues to prioritize gender equality, it is also institutionalizing frameworks that move from a genderonly focus towards a focus on multiple inequalities (Krizsan and Zentai). ${ }^{2}$ There are some important trends within Ukraine that align with this shift. For example, the National Program on Ensuring Equal Rights and Opportunities for Men and Women until 2016 mentions the need to look at the intersection of age and gender. Beyond such official government documents, a diverse range of inequities has been revealed in Ukraine over the last two decades. These include ethnic (e.g., among Roma women, Crimean Tatars, ethnic minorities, and refugees); geographic (e.g., among populations residing in villages, the ghost towns of Donetsk region and other oblasts in the East and South); and sexual inequities (e.g., the anti-gay movements and the wide-spread of homophobia). All these demonstrate the complexities and interconnection between many different forms of oppression and discrimination. As new groups seek equity for themselves, they may also create momentum and provide strength to challenge antigender movements more effectively. Moreover, the current political crisis (the Euromaidan, the invasion of the Crimea) may in fact provide a window of opportunity to expand the equity agenda through policy, research and programing that can effectively subvert any future movements that undermine the protection of human rights and social justice.

\section{Works Cited}

“10 lypnia sesiini slukhannia (materialy)." Ofitsiinyi sait Volyns'koi oblasnoi rady. Volyns'ka oblasna rada. 10 July 2012. Web. 1 June 2014. $<$ http://volynrada.gov.ua/news/10-lipnya-sesiini-slukhannya-materiali>.

Adkins, Roger. "Where 'Sex' Is Born(e): Intersexed Births and the Social Urgency of Heterosexuality." Journal of Medical Humanities 20.2 (1999): 117-133. Print.

Bingham, Natasha. "Gendering Civil Society: Women's Organizations in Former Soviet Republics." Diss. Loyola University, 2012. Print.

Binnie, Jon, and Christian Kless. "Solidarities and Tensions: Feminism and Transnational LGBTQ Politics in Poland." European Journal of Women's Studies 19.4 (2012): 444-459. Print.

Braithwaite, Ann. "Politics of/and Backlash." Journal of International Women's Studies 5.5 (2004): 18-33. Print.

Brown, Wendy, ed. States of Injury: Power and Freedom in Late Modernity. Princeton, N.J.: Princeton University Press, 1995. Print.

\footnotetext{
2 One foundation for this development is Article 13 of the Amsterdam Treaty (1997), which identifies sex, racial and ethnic origin, disability, age, religion, and sexual orientation as potential sources of discrimination.
} 
Browne, Victoria. "Backlash, Repetition, Untimeliness: The Temporal Dynamics of Feminist Politics." Hypatia 28.4 (Fall 2013): 905-920. Web. 10 July 2014.

Carrera, María Victoria, Renée DePalma, and Maria Lameiras. "Sex/Gender Identity: Moving Beyond Fixed and 'Natural' Categories." Sexualities 15.8 (2010): 9951016. Print.

Cassell, Justine, and Henry Jenkins, eds. From Barbie to Mortal Kombat: Gender and Computer Games. Massachusetts: MIT Press, 2000. Print.

Cherney, Isabelle D., and Kamala London. "Gender-linked Differences in the Toys, Television Shows, Computer Games, and Outdoor Activities of 5-to 13-year-old Children." Sex Roles 54.9-10 (2006): 717-726. Print.

"Children in Ukraine." www.unicef.org. UNICEF. Web. 1 June 2014. <http://www.unicef.org/ukraine/children.html>.

Coalition of Ukrainian NGOs. "Report to the UN Universal Periodic Review. Fourteenth session of the UN Human Rights Council on Universal Periodic Review 2nd Cycle." Ukrainian Helsinki Human Rights Union. UHHRU. 26 Mar 2012. Web. 1 June 2014. <http://helsinki.org.ua/en/ index.php?id=1337406407>.

Coalition of Ukrainian NGOs. "Ukraine: Review of Ukraine at the United Nations Human Rights Committee 108 $8^{\text {th }}$ Session." Ukrainian Helsinki Human Rights Union. June 2013. Web. 1 June 2014. <http://www2.ohchr.org/ english/bodies/hrc/docs/ngos/HRHF_Ukraine_HRC108.pdf>.

Committee on Women's Rights and Gender Equality. "Report on eliminating gender stereotypes in the EU (2012/2116(INI))." 6 Dec 2012. European Parliament. Web. 1 June 2014. <http://www.europarl.europa.eu/sides/getDoc.do? pubRef=-//EP//TEXT+REPORT+A7-2012-0401+0+DOC+XML+V0//EN >.

Connell, Raewyn. Gender. Cambridge: Polity, 2002. Print.

Coward, Rosalind. Sacred Cows: Is Feminism Relevant to the New Millennium? Hammersmith, London: HarperCollins, 2012. Print.

Davis, Kathy. "Feminist (Hi)stories." European Journal of Women's Studies 19.3 (2012): 279-281. Print.

The Dangers of Juvenile Justice. Kyiv, 2012. Film in possession of the authors.

"Deputaty L'vivs'koi oblrady vzialysia za heiv ta lesbiiok." 22 Feb 2011. Zakhid.net. Web. 1 June 2014. <http://zaxid.net/home/showSingleNews.do?deputati_ lvivskoyi_oblradi_vzyalisya_za_geyiv_ta_lesbiyok\&objectld=1123296>

Devor, Aaron, and Nicholas Matte. "Building a Better World for Transpeople: Reed Erickson and the Erickson Educational Foundation." International Journal of Transgenderism 10.1 (2007): 47-68. Print.

Dovbush, Dmytro. "Kruhlyi stil na temu hendernoi polityky ta IuIu." 8 Mar 2012. Relehiino-informatsiina sluzhba Ukrainy. Web. 1 June 2014. <http:// risu.org.ua/ua/index/blog/ vavrynyuk/47201/>.

Elam, Diane. "Sisters are Doing It to Themselves." Generations: Academic Feminists in Dialogue. Ed. Devoney Looser and Anne E. Kaplan. Minneapolis: University of Minnesota Press, 1997. 55-68. Print.

Elder, Miriam. "Feminism Could Destroy Russia, Russian Orthodox Patriarch Claims." 9 Apr 2013. The Guardian. Web. 2 June $2014 . \quad<$ http:// www.guardian.co.uk/world/2013/apr/09/feminism-destroy-russia-patriarchkirill>. 
Euromonitor International. Ukraine in 2030: The Future Demographic. Mar 2014. Euromonitor International. Web. 1 June 2014. <http://www.euromonitor.com/ ukraine-in-2030-the-future-demographic/report>.

Faludi, Susan. Backlash: The Undeclared War Against American Women. New York: Crown, 1991. Print.

Fausto-Sterling, Anne. Sex/Gender: Biology in a Social World. New York: Routledge, 2012. Print.

Feministychny ofenzyva. Web. 1 June 2014. <http://ofenzyva.wordpress.com>.

Findlay, Deborah. "Discovering Sex: Medical Science, Feminism and Intersexuality." Canadian Review of Sociology/Revue Canadienne de Sociologie 32.1 (1995): 2552. Print.

Funk, Nanette, and Magda Mueller. Gender Politics and Post-Communism: Reflections from Eastern Europe and the Former Soviet Union. New York: Routledge, 1993. Print.

Galligan, Yvonne, Sara Clavero, and Marina Calloni. Gender Politics and Democracy in Post-Socialist Europe. Opladen, Germany: Barbara Budrich Publishers, 2007. Print.

Gender bez prikras. Cherez gendernuiu politiku $k$ diktature homoseksualizma. Kyiv: Vse-ukrainskoe roditel'koe dvizhenie, 2010-11. Web. 1 June 2014. <http:// stopgender.files.wordpress.com/2011/04/broshura-gender-bez-prikras1.pdf>

Genderne 'vykhovannia' abo iak $z$ vashykh ditei robytymut' homoseksualistiv. Chastyna I. Dytiachi sadochky. Informatsiino-analitychne vydannia. Kyiv: n.p. 2012. Web. 1 June 2014. <http://stopgender.files.wordpress.com/2012/ 01/genderne-vihovannja.pdf>.

Graff, Agnieszka. "In a Different Chronology: Reflections on Feminism in Contemporary Poland." Third-Wave Feminism: A Critical Exploration. Ed. S. Gills, G. Howie and R. Munford. New York: Palgrave MacMillan, 2007. 142-155.

Hankivsky, Olena, and Anastasiya Salnykova, eds. Gender, Politics and the State in Ukraine. Toronto: University of Toronto Press, 2007. Print.

Higgins, Andrew. "Ukrainian Church Faces Obscure Pro-Russia Revolt in Its Own Ranks." The New York Times June 21, 2014. Web. 25 June 2014. <http://www.nytimes.com/2014/06/22/world/europe/ukrainian-churchfaces-obscure-pro-russia-revolt-in-its-own-ranks.html>.

Hovorun, T., and 0 . Kikinezhdi. "Hender u sotsial'no-psykholohichnomu vymiri." 1 Jan. 2008. Henderna dyskryminatsiia $v$ sferi osvity. Web. 1 June 2014. <http://helsinki.org.ua/index.php?id=1200305760>.

Hrycak, Alexandra. “Orange Harvest?: Women's Activism and Civil Society in Ukraine, Belarus and Russia since 2004." Canadian-American Slavic Studies 44.1-2 (2010): 151-177. Print.

Hrydkovets', L. M. "Hendernorivnisnyi ekstremizm iak faktor ruinatsii rodyny." Naukovi studii iz sotsial'noi ta politychnoi psykholohii: zbirnyk statei. NAPN Ukrainy, In-t. sotsial'noi ta politychnoi psykholohii. Vyp. 27 (30). Ed. M. M. Sliusarevs'kyi, V. H. Kremen', S. D. Maksymenko et. al. Kyiv: Milenium, 2011. 301-311. Print.

"Intermediate 2010 Report on Accomplishment of Recommendations Ukraine received in 2008 during the Universal Periodic Review under the UN Council on 
Human Rights" Ministerstvo zakordonykh sprav Ukrainy. Web. <http://www.mfa.gov.ua/mfa/ua/publication/content/48233.htm>.

Judge, Timothy A., and Beth A. Livingston. "Is the Gap More than Gender? A Longitudinal Analysis of Gender, Gender Role Orientation, and Earnings." Journal of Applied Psychology 93.5 (2008): 994-1012. Print.

Karpenko, Ksenia. "Ukrainian Feminism under Investigation." 1 April 2010. www.whatson-kiev.com. Web. 1 June 2014. <http://www.whatson-kiev.com/ index.php?go $=$ News\&file $=$ print $\& i d=8353>$.

Kis, Oksana. "Feminism in Contemporary Ukraine: From 'Allergy' to Last Hope." $A$ Report on the Condition of Culture and NGOs in Ukraine. Ed. P. Laufer, M. Riabchuck and A. Sawenec. Lublin: Open Culture Foundation, 2012. 264-277. Kultura enter. Web. 25 June 2014. <http://en.kulturaenter.pl/feminism-incontemporary-ukraine/2013/03/>.

Krizsan, Andrea, and Viola Zentai. "Institutionalizing Intersectionality in Central and Eastern Europe: Hungary, Poland, Romania and Slovenia." Institutionalizing Intersectionality: The Changing Nature of European Equality Regimes. Ed. Andrea Krizsan, Hege Skjeie and Judith Squires. Basingstoke: Palgrave MacMillan, 2012. 179-207. Print.

Kuehnast, Kathleen, and C. Nechemias. Post-Soviet Women Encountering Transition: Nation-building, Economic Survival, and Civic Activism. Washington, DC: Woodrow Wilson Center Press, 2004. Print.

Liubov' protiv homoseksualizma. n.d. Web. 1 June 2014. <http://love-contra.org>.

"Lviv Regional State Administration's Decree №867/0/5-12 Creates Ground for Gender Genocide in Lvivschyna" (in Ukrainian). Letter in possession of the authors.

Mahon, Rianne, and Fiona Williams, eds. Special Issue: Gender and State in PostCommunist Societies. Social Politics 14.3 (2007). Print.

Marsh, Rosalind J., ed. Women in Russia and Ukraine. Cambridge: Cambridge UP, 1996. Print.

Martsenyuk, Tamara. "The State of the LGBT Community and Homophobia in Ukraine." Problems of Post-Communism 59.2 (2012): 51-62. Print.

Ministerstvo iustytsii Ukrainy. "Roz'iasnennia. Pro rozhliad zvernen' hromadian stosovno rozvytku kryminal'noi iustytsii shchodo nepovnolitnikh v Ukraini ta gendernoi polityky." 22 March 2012. Verkhovna rada Ukrainy. Ofitsiinyi vebportal. Web. 1 June 2014. <http://zakon2.rada.gov.ua/laws/show/n0005323$12>$.

Murphy, Meghan. "There is a Wrong Way to do Feminism. And Femen is Doing it Wrong." 31 Oct 2012. Feminist Current Blog. Web. 1 June 2014. <http:// rabble.ca/blogs/bloggers/feminist-current/2012/10/there-wrong-way-dofeminism-and-femen-doing-it-wrong>.

Nash Mir (Our World) Gay and Lesbian Centre. One Step Forward, Two Steps Back: Situation of LGBT People in Ukraine in 2010-2011. Kyiv: Nash Mir, 2011. Web. 1 June 2014. <http://www.gay.org.ua/publications/report2011-e.pdf>.

Nordic Council. Hvordan motarbeide antifeminism og høyreekstremisme. Innspill og anbefalinger fra eksperter i norden. Oslo: Reform ressurssenter for menn, 2012. Web. 1 June 2014. <http://www.nrk.no/contentfile/file/1.10947191 \%21reform.pdf>. 
OECD. Social Institutions and Gender Index. Understanding the Drivers of Gender Inequality. Paris: OECD Development Centre, 2012. Web. 1 June 2014. <http://www.oecd.org/dev/50288699.pdf>.

"Information of the Ukrainian Parliament Commissioner for Human Rights to the United Nations Human Rights Committee within the framework of consideration of the 7th periodic report of Ukraine on the observance of the International Covenant on Civil and Political Rights." Office of the High Commissioner for Human Rights. United Nations Human Rights. Web. 1 June 2014. <http://www2.ohchr.org/English/bodies/hrc/docs/NGOs/ UPCHR_Ukraine_HRC108_en.doc>.

“Otets' Pavlo: 'V krainu zavezly troians'koho konia'." 20 Nov 2012. Kam'ianets'Podil's'kyi Khroniker. Portal kul'tury i mystetstva. Web. 1 June 2014. <http://www.hroniker.net/publ/religija/otec_pavlo_v_krajinu_zavezli_trojansk ogo_konja/29-1-0-668\#sthash.LkmLehSq.dpuf>.

Plakhotnik, Olga. "Gender Policy and Education in Contemporary Ukraine: Discourses and Controversies in Ukraine." Gender, Politics and the State in Ukraine. Ed. Olena Hankivsky and Anastasia Salnykova. Toronto: University of Toronto Press, 2012. 225-252. Print.

Plakhotnik, Olga. "K voprosu ob institutisializatsii gendernykh issledonanii kak uchebnoi distsipliny v sovremennoi Ukraine." Gendernye issledovaniia 19 (2009): 156-65. Print.

Reis, Elizabeth. "Divergence or Disorder?: The Politics of Naming Intersex." Perspectives in Biology and Medicine 50.4 (2007): 535-543. Print.

Rubchak, Marian J., ed. Mapping Difference: The Many Faces of Women in Contemporary Ukraine. London: Berghahn, 2011. Print.

Sauer, Birgit. "Bringing the State Back In: Civil Society, Women's Movements, and the State." Civil Society and Gender Justice: Historical and Comparative Perspectives. Eds. Karen Hagemann, Sonya Michel, and Gunilla Budde. New York, NY: Berghahn Books, 2008. 285-301. Print.

“Semeinyi karnaval 'Liubov' protiv homoseksualizma,' Kiev, 19.09.2009." Photograph 219. Web. 1 June 2014. <http://lovecontra.org/index.php/gallery/image_full/219/>.

"Semeinyi karnaval 'Liubov' protiv homoseksualizma,' Kiev, 19.09.2009." Photograph 224. Web. 1 June $2014 . \quad<$ http://lovecontra.org/index.php/gallery/image_full/224/>.

Semikolenova, Elena. "Gender Analysis of School Textbooks in Ukraine." Gender, Politics and the State in Ukraine. Ed. Olena Hankivsky and Anastasia Salnykova. Toronto: University of Toronto Press, 2012. 252-281.

Skoryk, M. M. "Praktyky navchannia gendernomu meinstriminhu v Ukraini: deiaki uroky." Genderni pidkhody u sferi derzhavnoi sluzhby ta sluzhby v orhanakh mistevoho samovriaduvannia. Materialy mizhnarodnoi naukovo-praktychnoi konferentsii. Lutsk: n.p., 2012. 73-78. Print.

"Statement by the representative of Ukraine at the Third Committee on the agenda item 28 'Advancement of Women' (16 October 2012, New York)." www.un.org. Web. 1 June 2014. <http://www.un.org/womenwatch/daw/documents/ga67/ Ukraine.pdf $>$.

Stop Gender. Kyiv, 2011. Film in possession of the authors. 
Stop-Gender. n.d. Web. 1 June 2014. <http://stopgender.wordpress.com/>.

Štulhofer, Aleksandar, and Theo Sandfort, eds. Sexuality and Gender in Postcommunist Eastern Europe and Russia. Binghampton: Haworth, 2005. Print.

"Ukraina bez syrit, chy Ukraina bez ditei." 8 Feb 2013. YouTube. Web. 1 June 2014. <http://www.youtube.com/watch?v=crhYNM03eI8>.

"Ukraine: Investigate Violence Against LGBT Activists." Human Rights Watch. 31 May 2013. Web. 1 June 2014. <http://www.hrw.org/news/2013/05/30/ukraineinvestigate-violence-against-lgbt-activists>.

United Nations, Department of Economic and Social Affairs, Population Division. World Population Prospects: The 2012 Revision, Key Findings and Advance Tables. Working Paper No. ESA/P/WP.227. New York: United Nations, 2013. Web. 1 June 2014. <http://esa.un.org/unpd/wpp/Documentation/ pdf/WPP2012_\%20KE\%20FINDINGS.pdf>.

UNRISD. Religion, Politics, and Gender Equality. UNRISD Research and Policy Brief 11. Geneva: UNRISD, 2011. Web. 1 June 2014. <http://www.unrisd.org/ 80256B3C005BCCF9/httpNetITFramePDF?ReadForm\&parentunid=EE0F97F5 1F026825C1257894004E4F69\&parentdoctype=brief\&netitpath $=80256 \mathrm{~B} 3 \mathrm{C00}$ 5BCCF9/(httpAuxPages)/EE0F97F51F026825C1257894004E4F69/\$file/RPB1 1 e.pdf $>$.

Wei, Fang-Yi Flora, and Katherine Grace Hendrix. "Gender Differences in Preschool Children's Recall of Competitive and Noncompetitive Computer Mathematics Games." Learning, Media and Technology 34.1 (2009): 27-43. Print.

World Health Organization. "Gender, Women and Health: What Do We Mean by 'Sex' and 'Gender'?” www.who.int. Web. 1 June 2014. http://www.who.int/ gender/whatisgender/en/.

Yorick, Roman, Halyna Skipalska, Svetlana Suvorova, Olga Sukovatova, Konstantin Zakharov, and Sara Hodgdon. "HIV Prevention and Rehabilitation Models for Women who Inject Drugs in Russia and Ukraine." Advances in Preventive Medicine. 2012. Web. 1 June 2014. <http://www.hindawi.com/journals/apm/ 2012/316871/>.

Yu, Su-lin. "Across East and West: Third Wave Feminism as a Traveling Theory." Asian Women 28.1 (2012): 65-83. Print. 
